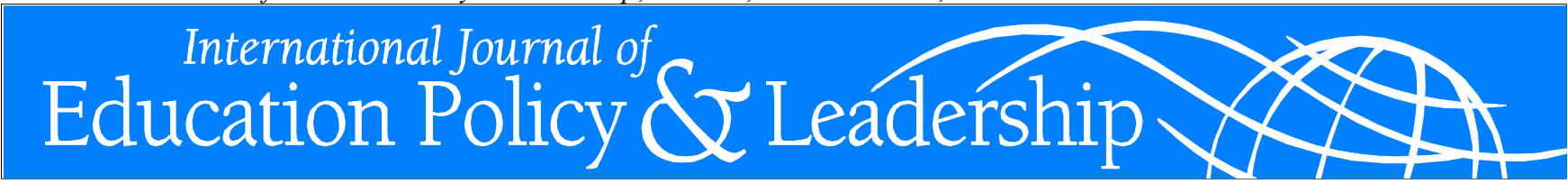

\title{
STAKEHOLDER PERCEPTIONS OF BARRIERS AND SOLUTIONS TO SIGNIFICANT EXPANSION OF POSTSECONDARY ENROLLMENT OPTIONS FOR HIGH SCHOOL STUDENTS
}

\author{
CARL WOZNIAK \\ Northern Michigan University \\ LOUANN BIERLEIN PALMER \\ Western Michigan University
}

\begin{abstract}
Post-secondary experiences for students still in high school have been promoted as a means to increase academic rigor and create a bettertrained workforce. Yet little is known regarding supports needed to significantly increase such options. This study obtained input from 411 stakeholders in one Midwestern state, including 201 district superintendents, 181 high school principals, and 23 college dual enrollment officers regarding their use of these options, their perceptions of barriers to program expansion, and their ranking of possible solutions to overcome the barriers. Findings demonstrate that all parties find postsecondary options of value, with traditional dual enrollment the most used option. Although all groups identified funding as a primary barrier, other systemic barriers were of great concern. Participants suggest that expansion of Advanced Placement and early and middle college programs, financial assistance for dually enrolled students, and increased program availability for career and technical options would be beneficial.
\end{abstract}

Wozniak, C. \& Bierlein Palmer, L. (2013). Stakeholder Perceptions of Barriers and Solutions to Significant Expansion of Postsecondary Enrollment Options for High School Students. International Journal of Education Policy \& Leadership 8(2). Retrieved from www.ijepl.org

\section{Introduction and Background}

As America's workforce needs continue to change, greater emphasis is being placed on postsecondary educational achievement. Individuals with only a high school diploma (or less) have limited ability to secure middleincome level positions. This is particularly true in the United States Midwest, where the auto industry provided undereducated workers with substantial wages for many decades.

Michigan, once prosperous and the focus of this study, was the only state to experience a net population loss between 2000 and 2010 (Berg-Anderson, 2011). In an era of greater expectations of employee acumen, a much stronger connection between $\mathrm{K}-12$ and higher education, and exploration of postsecondary educational options during the time students are still in high school, needs to be explored.

Postsecondary educational opportunity policy has been brought to the forefront several times by Michigan policymakers as they attempt to improve the state economy via a welleducated workforce. Nearly a decade ago, former Governor Jennifer Granholm formed a commission to recommend strategies for alleviating the economic crisis that had already begun to manifest. This Commission on Higher Education and Economic Growth (2004) was headed by Michigan Lieutenant Governor Jon Cherry (and nicknamed the "Cherry Commission"), and was charged with exploring changes to secondary and higher

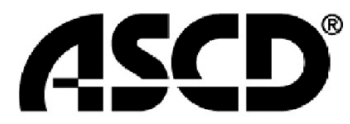

LEARN. TEACH. LEAD.
SElUSIMON FRASER UNIVERSITY THINKING OF THE WORLD

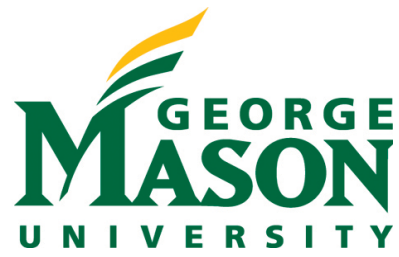


education that would help improve state economic growth.

The Cherry Commission proposed a significant increase in advanced educational opportunities for high school students through online and classroom-based postsecondary education. Specifically, the report recommended that 50 percent of Michigan's high school students be enrolled in some form of postsecondary education by 2015 (Cherry Commission, 2004). One of these forms, dual enrollment, was seen as an effective tool to create the more-educated population needed to successfully navigate the twenty-first century job market, and it was the primary focus of our study.

Michigan currently recognizes six types of postsecondary options for high school students, that are codified in the Postsecondary Educational Options Act of 1996 (PSEOA) and promulgated Department of Education rules (Hughes, Jacobs, \& Karp, 2006). These include Advanced Placement courses, International Baccalaureate programs, middle college, early college, online college credit courses, and dual enrollment.

At the time of the Cherry Commission's 2006 report only 7.03\% of Michigan students were participating in some form of dual enrollment (Michigan Department of Education, 2007). Although this was above the national average of about 5 percent (Kleiner, Lewis, \& Greene, 2005), it was far short of the suggested 50 percent participation goal for 2015 . Many questioned whether this goal could be accomplished under the current funding system (Hughes et al., 2006), or with the current capacities at colleges and universities. In addition, no data existed on stakeholder buy-in for this postsecondary options policy, and without such knowledge, the chances of successful implementation were minimized. It was within this context that we began our research study.

\section{Problem Statement and Research Questions}

Stakeholder theory describes the groups that are vested in an organization and provides recommendations regarding the best ways to incorporate their needs and concerns (Freeman, 1998; Freeman \& McVea, 2001). A critical component of this theory is that the stakeholders include a broader group of individuals than either the rule makers or individuals financially tied to an organization (Donaldson \& Preston, 1995). Additionally, Fuhrman, Clune, and Elmore (1988) indicated that successful implementation of policy at the local level is more pervasive if the local stakeholders are actively engaged in the reform process. As a consequence, in order for Michigan (or other states) to possibly meet a goal of significantly increasing postsecondary dual enrollments, the concept must have buy-in by critical administrator stakeholders who are charged with local implementation. As extracted from various national and state reports, several areas of concern can hamper such implementation.

\section{Areas of Concern}

Dual enrollment in Michigan places a financial burden on participating high schools by requiring that schools use foundation grant funds, the per-pupil funds provided by the state to the schools for operations, to pay for postsecondary tuition (Michigan Department of Education, 2006b). No additional funding is provided by the state to schools to help cover the costs of dual enrollment, and colleges are under no obligation to provide services to dually enrolled students at reduced costs (Michigan Legislative Council, 1996). Although schools and colleges are encouraged to develop articulation agreements that reduce expenditures (Michigan Department of Education, 2012), the mandated burden primarily falls on the local school districts. The Cherry Commission (2004) had recommended that this funding mechanism be revised, but to date no such legislation has been enacted in Michigan.

Student access and equitability issues are also a concern. Numerous studies have demonstrated a clear link between socioeconomic status, high school course selection, and college readiness (Brand, 2005; Hoffman, 2005; 
Hughes, Karp, Fermin, \& Bailey, 2005; Karp, Bailey, Hughes, \& Fermin, 2004; Karp, Bailey, Hughes, \& Fermin, 2005a). Indeed, dual enrollment programs nationally have been heavily weighted toward advanced students and are often perceived as such by educators (Hoffman, 2005; Porter, 2003; Vargas, 2004). And although Michigan's program was expanded in 2000 to allow forms of career and technical education, only colleges and universities can offer dual enrollment (Michigan Legislative Council, 2000). Courses must take place either on a college campus or online, or be open to regular college students if offered on a high school campus. The law also requires that students must successfully pass state assessment measures prior to participation (Hughes et al., 2006).

A third area of concern involves various higher education readiness and faculty issues. Classic pedagogical instruction is much more teacher-directed and actively fosters dependency on the teacher, whereas andragogical (adult learner) instruction focuses on more student independence, motivation, and problem solving. College instructors, as a whole, have limited training in pedagogy, and younger students may need familiar ways of instruction to maximize learning (Hiemstra \& Sisco, 2007).

\section{Research Questions}

Michigan's Cherry Commission report identified the aforementioned and other barriers to significant expansion of postsecondary options, but was not charged with discovering ways to overcome such barriers. A later statelevel committee provided some recommended solutions (Hughes et al., 2006), but there appeared to be little effort to capture the broader opinions of key dual enrollment stakeholders and the potential solutions they might offer. Yet, as Rusaw (2007) notes, successful pluralistic models of change must have inclusive input of all relevant stakeholders. Only a few minor suggestions from this committee have been implemented to date.
Within this context of state-level policy goals, numerous barriers, and limited stakeholder input, our study examined the perceptions of Michigan school district superintendents, high school principals, and college/ university dual enrollment officers. The purpose of our study was to determine: (1) To what degree do high schools and colleges utilize postsecondary options programs; and (2) How do perceptions of efficacy of postsecondary programs offered in the state vary among stakeholder groups with regard to funding, student access, programmatic barriers and infrastructure issues, and solutions to overcoming the barriers?

This article summarizes the core findings from a larger study, with additional data found within Wozniak (2010). Although our study focused specifically on Michigan, these policy issues are also of interest in other states as they too make efforts to better link K-12 and higher education for students.

\section{Methodology}

Our study utilized a researcher-designed online survey of three Michigan stakeholder groups: dual enrollment officers in two- and four-year colleges; school district superintendents; and high school principals or their designees. The survey was developed using prior findings regarding barriers and suggested solutions to postsecondary option issues, particularly those noted by Hughes et al. (2006), the Secondary to Postsecondary Transition Action Team (2006), and Burt and Snyder (2006).

The instrument consisted of an online skiplogic questionnaire, distributed through Qualtirx that was identical for all participant groups, with the exception of demographic and dual enrollment acceptance questions that were not appropriate for all groups. The survey included 17 barrier statements and 13 solution statements to which participants were asked to indicate their level of agreement using four- and five-point rating scales. Additionally, participants were queried regarding their institution's participation in the various postsecondary modalities available in the state. 
Open-ended response opportunities allowed for unanticipated responses and elaboration. Pilot testing enhanced content validity. Following HSRIB approval, participants were contacted via email by the Michigan Department of Education's dual enrollment officer and asked to participate in the study.

\section{Results}

Responses were received from 411 individuals, resulting in an overall response rate of 29.8percent. This included responses from 201 district superintendents (36.5 percent response rate); 181 high school principals or designees (24.1 percent response rate); and 23 college dual enrollment officers (38.7 percent response rate). Respondents provided the zip code for their organizations, which allowed us to affirm that data included a geographically diverse group of districts, high schools, and higher education institutions (all throughout the state of Michigan). The following sections report the key results.

\section{Program Participation}

Traditional in-class dual enrollment was identified as the top postsecondary option, with 89 percent of superintendents, 83 percent of high schools, and 100 percent of colleges indicating participation (see Table 1). Online dual enrollment programs and AP were utilized to a similar degree, with approximately 80 percent of superintendents 76 percent of principals and 83 percent of colleges indicating utilization of these programs.

\section{Barriers to Greater Program Expansion}

Participants were asked to rank 17 possible barriers to expansion of postsecondary options, and Table 2 (next page) summarizes the rankings from greatest to least concerns. All groups identified poor levels of state funding and problems with course schedule alignment as concerns, with funding being the most severe issue. Limited acceptance of dual enrollment was also an issue for principals and superintendents, but not for college administrators.

District superintendents also indicated that distance from partner institutions is a concern, but this was only a moderate issue for other groups. School principals identified options for less gifted students as an additional barrier, a sentiment somewhat agreed with by superintendents but of only moderate concern to college dual enrollment officers.

College administrators primarily identified student-based issues as barriers to increasing

Table 1

Participation in Postsecondary Programs as Identified by School District, School, and College Administrators

\begin{tabular}{lccc}
\hline Program & $\begin{array}{c}\text { District } \\
\mathrm{n}(\%)\end{array}$ & $\begin{array}{c}\text { School } \\
\mathrm{n}(\%)\end{array}$ & $\begin{array}{c}\text { College } \\
\mathrm{n}(\%)\end{array}$ \\
\hline On-campus dual enrollment & $161(89.0)$ & $142(83.0)$ & $23(100.0)$ \\
Advanced placement & $139(76.8)$ & $138(81.2)$ & $23(100.0)$ \\
Online dual enrollment & $144(79.6)$ & $129(75.9)$ & $19(82.6)$ \\
Early college & $36(20.7)$ & $41(24.7)$ & $7(30.4)$ \\
International Baccalaureate & $10(5.7)$ & $13(7.9)$ & $14(60.9)$
\end{tabular}


postsecondary numbers. Student maturity, study skills, and academic ability were highly ranked concerns for college respondents, but were only a moderate concern for district and school officials. College respondents also identified limited support staff for dually enrolled students as a moderate barrier.

Although there is agreement among the participants that funding poses a problem for program implementation, major differences are noted between the college administrators and other respondents in several areas. These include the acceptance of dual enrollment credit, student shortcomings, and college instructor pedagogical skill.

\section{Funding Dual Enrollment}

Not surprisingly, administrators identified funding shortages as the largest barrier to enhancing postsecondary options. District superintendents, the holders of the schools' purse strings, view the funding issue as a greater concern than either high school principals or

Table 2

Barriers to Increased Dual Enrollment Rank-ordered Most to Least Significant

\begin{tabular}{|c|c|c|c|c|c|c|c|c|}
\hline \multirow[b]{2}{*}{ Barrier } & \multicolumn{2}{|c|}{ District } & \multicolumn{2}{|c|}{ School } & \multicolumn{2}{|c|}{ College } & \multicolumn{2}{|c|}{ Total } \\
\hline & Rank & $\overline{\mathbf{x}}$ & Rank & $\overline{\mathbf{x}}$ & Rank & $\overline{\mathbf{x}}$ & Rank & $\overline{\bar{x}}$ \\
\hline Low state funding levels & 1 & 2.2 & 2 & 2.7 & 3 & 2.7 & 1 & 2.5 \\
\hline Poor schedule alignment & 2 & 2.7 & 1 & 2.6 & 3 & 2.7 & 2 & 2.6 \\
\hline $\begin{array}{l}\text { Limited acceptance of dual en- } \\
\text { rollment credit }\end{array}$ & 3 & 2.9 & 3 & 2.9 & 17 & 3.9 & 3 & 2.9 \\
\hline $\begin{array}{l}\text { Limited courses for less-gifted } \\
\text { students }\end{array}$ & 5 & 3.0 & 3 & 2.9 & 8 & 3.3 & 4 & 3.0 \\
\hline $\begin{array}{l}\text { Excessive distance to partner } \\
\text { schools }\end{array}$ & 3 & 2.9 & 7 & 3.2 & 8 & 3.3 & 4 & 3.0 \\
\hline Poor HS student study skills & 6 & 3.1 & 5 & 3.0 & 2 & 2.6 & 4 & 3.0 \\
\hline Poor HS student maturity & 7 & 3.2 & 5 & 3.0 & 1 & 2.5 & 4 & 3.0 \\
\hline Insufficient faculty staffing & 7 & 3.2 & 10 & 3.3 & 7 & 3.0 & 8 & 3.2 \\
\hline Poor HS student academic ability & 10 & 3.3 & 7 & 3.2 & 3 & 2.7 & 8 & 3.2 \\
\hline Insufficient support staff & 10 & 3.3 & 10 & 3.3 & 6 & 2.9 & 8 & 3.3 \\
\hline Poor buy-in by our faculty & 7 & 3.2 & 14 & 3.4 & 8 & 3.3 & 8 & 3.3 \\
\hline Poor college pedagogy & 10 & 3.3 & 7 & 3.2 & 14 & 3.7 & 8 & 3.3 \\
\hline Limited computer infrastructure & 15 & 3.5 & 10 & 3.3 & 12 & 3.5 & 13 & 3.4 \\
\hline $\begin{array}{l}\text { Restrictive institutional eligibility } \\
\text { requirements }\end{array}$ & 13 & 3.4 & 14 & 3.4 & 12 & 3.5 & 13 & 3.4 \\
\hline $\begin{array}{l}\text { Restrictive state eligibility re- } \\
\text { quirements }\end{array}$ & 13 & 3.4 & 10 & 3.3 & 8 & 3.3 & 13 & 3.4 \\
\hline Safety concerns & 16 & 3.7 & 16 & 3.6 & 14 & 3.7 & 16 & 3.6 \\
\hline Poor buy-in by our administration & 17 & 3.8 & 17 & 3.8 & 16 & 3.8 & 17 & 3.8 \\
\hline Limited facilities* & & & & & 14 & 3.7 & & \\
\hline
\end{tabular}

Note. *Limited facilities question asked only of college respondents. Mean ( $\bar{x})$ values scale determined using: $1=$ Serious barrier, 2 = Moderate barrier, 3 = Slight barrier, 4 = Not a barrier. 
college administrators. As seen in Table 3, most superintendents (62.3 percent) perceived low state funding for postsecondary education as being a serious or moderate barrier, compared to 40.9 percent of high school principals and 47.6 percent of college dual enrollment officers.

It is interesting to note that 48.9 percent of individuals from all subgroups (the sum of "slight" and "not a barrier") do not consider the amount of state funding to be a significant barrier to expansion of postsecondary options.

\section{Student Access and Acceptance Poli- cies}

Participants rated statements regarding the adequacy of postsecondary options for "talented" and "less gifted" students. As shown in Table 4, most superintendents (69.1 percent), principals (80.7 percent) and college dual enrollment officers (85.9 percent) strongly or moderately agreed that dual enrollment options were adequate for talented students. Only 45.2 percent of superintendents, 47.9 percent of principals, and 52.2 percent of col-

Table 3

Low State Funding as a Barrier to Postsecondary Expansion

\begin{tabular}{lccccrr}
\hline & Serious barrier & \multicolumn{1}{c}{$\begin{array}{c}\text { Moderate } \\
\text { barrier }\end{array}$} & Slight barrier & Not a barrier & & Total \\
& $\mathrm{n}(\%)$ & $\mathrm{n}(\%)$ & $\mathrm{n}(\%)$ & $\mathrm{n}(\%)$ & $\overline{\mathrm{x}}$ & $\mathrm{n}(\%)$ \\
\hline District & $49(35.5)$ & $37(26.8)$ & $25(18.1)$ & $27(19.6)$ & 2.2 & $138(45.5)$ \\
School & $31(21.5)$ & $28(19.4)$ & $42(29.2)$ & $43(29.9)$ & 2.7 & $144(47.5)$ \\
College & $3(14.3)$ & $7(33.3)$ & $5(23.8)$ & $6(28.6)$ & 2.7 & $21(6.9)$ \\
Total & $83(27.4)$ & $72(23.8)$ & $72(23.8)$ & $76(25.1)$ & 2.5 & $303(100)$ \\
\hline
\end{tabular}

Note. Mean $(\overline{\mathrm{x}})$ based on rating scale responses: $1=$ Serious barrier, $2=$ Moderate barrier, $3=$ Slight barrier, $4=$ Not a barrier.

Table 4

Adequacy of Dual Enrollment Options by Student Ability

\begin{tabular}{|c|c|c|c|c|c|c|c|c|}
\hline & Strongly & Mod. Disagree & Slightly & Slightly Agree & Mod. Agree & \multicolumn{2}{|l|}{ Strongly Agree } & Total \\
\hline & $\mathrm{n}(\%)$ & $\mathrm{n}(\%)$ & $\mathrm{n}(\%)$ & $\mathrm{n}(\%)$ & $\mathrm{n}(\%)$ & $\mathrm{n}(\%)$ & $\bar{x}$ & $\mathrm{~N}$ \\
\hline \multicolumn{9}{|c|}{ Adequate Options Exist for Talented Students } \\
\hline District & $14(8.0)$ & $11(6.3)$ & $9(5.1)$ & $20(11.4)$ & $59(33.7)$ & $62(35.4)$ & 4.6 & 175 \\
\hline School & $6(3.6)$ & $6(3.6)$ & $5(3.0)$ & $15(9.1)$ & $42(25.5)$ & $91(55.2)$ & 5.1 & 165 \\
\hline College & $0(0.0)$ & $0(0.0)$ & $1(4.3)$ & $2(8.7)$ & $7(30.4)$ & $13(56.5)$ & 5.4 & 23 \\
\hline Total & $20(5.5)$ & $17(4.7)$ & $15(4.1)$ & $37(10.2)$ & $108(29.8)$ & $166(45.7)$ & 4.9 & 363 \\
\hline \multicolumn{9}{|c|}{ Adequate Options Exist for Less-Gifted Students } \\
\hline District & $14(8.0)$ & $18(10.3)$ & $20(11.4)$ & $44(25.1)$ & $50(28.6)$ & $29(16.6)$ & 4.1 & 175 \\
\hline School & $11(6.7)$ & $14(8.5)$ & $16(9.7)$ & $45(27.3)$ & $37(22.4)$ & $42(25.5)$ & 4.3 & 165 \\
\hline College & $2(8.7)$ & $2(8.7)$ & $4(17.4)$ & $3(13.0)$ & $6(26.1)$ & $6(26.1)$ & 4.2 & 23 \\
\hline Total & $27(7.4)$ & $34(9.4)$ & $40(11.0)$ & $92(25.3)$ & $93(25.6)$ & $77(21.2)$ & 4.2 & 363 \\
\hline
\end{tabular}

Note. Mean $(\overline{\mathrm{x}})$ values calculated using scalar values of 1 for "strongly disagree" to 6 for "strongly agree." 
lege respondents had the same opinion regarding options for less-gifted students.

\section{Dual Enrollment Acceptance Policies}

Three-quarters of two-year colleges accepted other institutions' dual enrollment credits without restriction; although no private fouryear institutions did (see Table 5). Public fouryear institutions were essentially equally divided on this point, with five accepting credits without restriction and four indicating that some restrictions applied.

Our findings indicate that colleges generally accept their own dual enrollment credits without exception, but have varying degrees of acceptance of credits earned at other institutions. For four-year public colleges there was a fairly equal split between institutions that accepted dual enrollment credit from other institutions without restriction and those that first compared the other institutions' courses with their own prior to awarding credit. Public community colleges had the highest likelihood of accepting dual enrollment credit without restriction (75.0 percent), and also the highest rate of acceptance by comparing their own courses with the dual enrollment courses (58.3 percent).

\section{Student Preparedness and College Instructor Pedagogical Skill}

As noted in Table 1, college respondents ranked student maturity and study skills as the primary barriers to dual enrollment, with poor academic ability tied with two other categories for third place. As seen in Table 6 (next page), 45 percent of college respondents considered student study skills to be either a serious or moderate barrier to success. Only 27 percent of principals and 16.6 percent of superintendents agreed.

Most college participants (75.0 percent) did not view college professor pedagogical teaching skills as a serious or moderate problem, although only about half of principals (47.1 percent) and superintendents (50.9 percent) agreed. Clearly, expectations of school and college respondents vary. Seemingly, colleges expect students to conform to a new educational paradigm and school administrators expect college instructors to maintain some aspect of the teaching methodology to which the students are accustomed.

Table 5

College Dual Enrollment Acceptance Policies

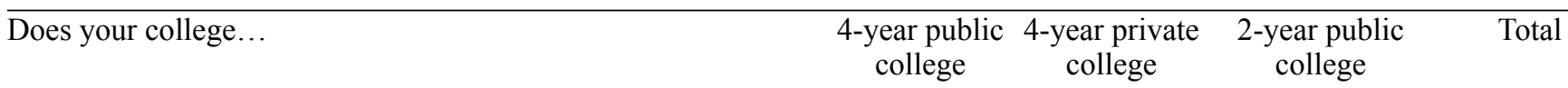

\begin{tabular}{|c|c|c|c|c|c|}
\hline \multirow{2}{*}{$\begin{array}{l}\text { 1) Accept DE credit taken at our own institu- } \\
\text { tion without restrictions }\end{array}$} & Yes n $(\%)$ & $7(87.5)$ & $2(100.0)$ & $12(100.0)$ & $21(95.5)$ \\
\hline & No $n(\%)$ & $1(12.5)$ & $0(0.0)$ & $0(0.0)$ & $1(4.5)$ \\
\hline \multirow{2}{*}{$\begin{array}{l}\text { 2) Accept DE credit taken at other institutions } \\
\text { without restrictions }\end{array}$} & Yes n $(\%)$ & $5(55.6)$ & $0(0.0)$ & $9(75.0)$ & $14(60.9)$ \\
\hline & No $\mathrm{n}(\%)$ & $4(44.4)$ & $2(100.0)$ & $3(25.0)$ & $9(39.1)$ \\
\hline \multicolumn{2}{|c|}{ 3) Only accept DE credit from other institutionsYes $n(\%)$} & $4(44.4)$ & $1(100.0)$ & $7(58.3)$ & $12(54.6)$ \\
\hline $\begin{array}{l}\text { after comparing substance of course to } \\
\text { own courses }\end{array}$ & No $n(\%)$ & $5(55.6)$ & $0(0.0)$ & $5(41.7)$ & $10(45.4)$ \\
\hline \multicolumn{2}{|c|}{ 4) Accept DE credits for courses also appearing Yes $\mathrm{n} \%$ ) } & $3(37.5)$ & $2(100.0)$ & $9(75.0)$ & $14(63.6)$ \\
\hline on student's HS transcript & No $n(\%)$ & $4(50.0)$ & $0(0.0)$ & $3(25.0)$ & $7(31.8)$ \\
\hline
\end{tabular}


Table 6

Inadequate Student Preparation as a Barrier to Dual Enrollment

\begin{tabular}{|c|c|c|c|c|c|c|}
\hline & $\begin{array}{c}\text { A serious } \\
\text { barrier } \\
\mathrm{n}(\%)\end{array}$ & $\begin{array}{c}\text { A mod. } \\
\text { Barrier } \\
\mathrm{n}(\%)\end{array}$ & $\begin{array}{c}\text { A slight } \\
\text { barrier } \\
\mathrm{n}(\%)\end{array}$ & $\begin{array}{c}\text { Not a } \\
\text { barrier } \\
\mathrm{n}(\%)\end{array}$ & $\bar{x}$ & $\begin{array}{c}\text { Total } \\
\mathrm{N}\end{array}$ \\
\hline \multicolumn{7}{|c|}{ Poor HS student academic ability } \\
\hline District & $8(5.9)$ & $10(7.4)$ & $57(42.2)$ & $60(44.4)$ & 3.3 & 135 \\
\hline School & $9(6.3)$ & $19(13.4)$ & $52(36.6)$ & $62(43.7)$ & 3.2 & 142 \\
\hline College & $3(15.0)$ & $5(25.0)$ & $7(35.0)$ & $5(25.0)$ & 2.7 & 20 \\
\hline Total & $20(6.7)$ & $34(11.4)$ & $116(39.1)$ & $127(42.8)$ & 3.2 & 297 \\
\hline \multicolumn{7}{|c|}{ Poor HS student study skills } \\
\hline District & $6(4.3)$ & $17(12.3)$ & $69(50.0)$ & $46(33.3)$ & 3.1 & 138 \\
\hline School & $15(10.5)$ & $23(16.1)$ & $58(40.6)$ & $47(32.9)$ & 3.0 & 143 \\
\hline College & $4(20.0)$ & $5(25.0)$ & $6(30.0)$ & $5(25.0)$ & 2.6 & 20 \\
\hline Total & $25(8.3)$ & $45(15.0)$ & $133(44.2)$ & $98(32.6)$ & 3.0 & 301 \\
\hline \multicolumn{7}{|c|}{ Poor HS student maturity } \\
\hline District & $6(4.3)$ & $11(8.0)$ & $75(54.3)$ & $46(33.3)$ & 3.2 & 138 \\
\hline School & $8(5.7)$ & $27(19.3)$ & $67(47.9)$ & $38(27.1)$ & 3.0 & 140 \\
\hline College & $3(15.0$ & $7(35.0)$ & $8(40.0)$ & $2(10.0)$ & 2.5 & 20 \\
\hline Total & $17(5.7)$ & $45(15.1)$ & $150(50.3)$ & $86(28.9)$ & 3.1 & 298 \\
\hline \multicolumn{7}{|c|}{ Incompatible College Instructor Pedagogical Skills } \\
\hline District & $4(2.5)$ & $27(16.6)$ & $49(30.1)$ & $83(50.9)$ & 3.3 & 163 \\
\hline School & $10(6.4)$ & $15(9.6)$ & $58(36.9)$ & $74(47.1)$ & 3.2 & 157 \\
\hline College & $0(0.0)$ & $2(10.0)$ & $3(15.0)$ & $15(75.0)$ & 3.7 & 20 \\
\hline Total & $14(4.1)$ & $44(12.9)$ & $110(32.4)$ & $172(50.6)$ & 3.3 & 340 \\
\hline
\end{tabular}

Note. Mean ( $\overline{\mathrm{x}})$ derived from the provided scale: $1=$ Serious barrier, $2=$ Moderate barrier, $3=$ Slight barrier, $4=$ Not a barrier.

\section{Solutions for Greater Implementation of Postsecondary Programs}

Participants were offered 13 statements of possible solutions to issues that inhibit increasing postsecondary options for high school students, and asked to what extent they believe these should be implemented. The solution statements were derived from previously published studies, articles, and contracted reports (Bailey, 2005; Frenette, 2006; Hagedorn \& Fogel, 2002; High School Leadership Summit, 2004; Hoffman \& Vargas, 2005; Hughes et al., 2006; Karp, Bailey, Hughes, \& Fermin, 2005b; Lerner \& Brand, 2006; Michigan Department of Education, 2006a). Table 7 (next page) offers these solutions as ranked by the overall mean, with higher numbers indicating a stronger desire to pursue a given solution.

Both superintendents and principals identified increasing early and middle college options (typically a joint venture of the state, a college, and schools that are geographically close to the college) as the highest-priority solution to increase postsecondary opportunities for students. This is part of a broader suggestion by the schools that offerings for lesstalented individuals be expanded, and includes expansion in career and technical preparatory areas and allowance of organizations other 
than colleges to offer dual enrollment. These changes would have the greatest impact on nontraditional dually enrolled students, namely those not typically college-bound.

School administrators also had a stronger belief that students should be responsible for a more significant share of expenses related to college dual enrollment than college respondents. About a third of principals (33.3 percent) and superintendents (31.8 percent) believed that students have too little responsibility for costs associated with postsecondary education. Only 5.3 percent of college administrators shared this belief.

College administrators viewed additional financial aid to students as the primary tool to increase dual enrollment, but they were also supportive of expansion of early/middle colleges and career and technical preparatory options. The findings indicate an operational dilemma, however, in that the desire to increase program options for less talented students is countered by the lack of desire by all respondent groups to effect change at the state level that would be necessary to fully implement such programs. The lowest ranking options for all groups related to eligibility of students who are able to participate in dual enrollment. All sub-groups ranked elimination of current eligibility and grade-level requirements with the lowest priority.

To fully incorporate postsecondary options for all students, particularly to those of lower academic ability, policies regarding eligibility

Table 7

Rank-ordered Solutions to Increase Dual Enrollment

\begin{tabular}{|c|c|c|c|c|c|c|c|c|}
\hline \multirow[t]{2}{*}{ Solution } & \multicolumn{2}{|c|}{ District } & \multicolumn{2}{|c|}{ School } & \multicolumn{2}{|c|}{ College } & \multicolumn{2}{|c|}{ Total } \\
\hline & Rank & $\overline{\mathrm{X}}$ & Rank & $\overline{\mathrm{X}}$ & Rank & $\overline{\mathrm{X}}$ & Rank & $\overline{\mathrm{X}}$ \\
\hline Expand early and middle colleges & 1 & 3.3 & 1 & 2.6 & 4 & 2.1 & 1 & 2.7 \\
\hline $\begin{array}{l}\text { Provide financial assistance to dual } \\
\text { enrolled students }\end{array}$ & 5 & 2.9 & 3 & 2.5 & 1 & 2.6 & 1 & 2.7 \\
\hline $\begin{array}{l}\text { Increase Advanced Placement op- } \\
\text { portunities }\end{array}$ & 2 & 3.2 & 1 & 2.6 & 8 & 1.9 & 3 & 2.6 \\
\hline $\begin{array}{l}\text { Expand DE in career and technical } \\
\text { preparatory courses }\end{array}$ & 3 & 3.1 & 3 & 2.5 & 2 & 2.3 & 3 & 2.6 \\
\hline $\begin{array}{l}\text { Teach college courses in the high } \\
\text { school }\end{array}$ & 4 & 3.0 & 3 & 2.5 & 4 & 2.1 & 5 & 2.5 \\
\hline $\begin{array}{l}\text { Allow organizations other than col- } \\
\text { leges to offer DE }\end{array}$ & 5 & 2.9 & 3 & 2.5 & 10 & 1.6 & 5 & 2.5 \\
\hline $\begin{array}{l}\text { Provide specialized counseling for } \\
\text { DE students }\end{array}$ & 5 & 2.9 & 7 & 2.4 & 2 & 2.3 & 5 & 2.5 \\
\hline $\begin{array}{l}\text { Create a common K-16 database for } \\
\text { student information }\end{array}$ & 5 & 2.9 & 8 & 2.3 & 4 & 2.1 & 8 & 2.4 \\
\hline $\begin{array}{l}\text { Create a K-16 local council for } \\
\text { managing DE issues }\end{array}$ & 10 & 2.7 & 8 & 2.3 & 8 & 1.9 & 9 & 2.3 \\
\hline $\begin{array}{l}\text { Create a K-16 state council for } \\
\text { oversight of DE }\end{array}$ & 9 & 2.8 & 8 & 2.3 & 7 & 2.0 & 9 & 2.3 \\
\hline $\begin{array}{l}\text { Legislatively waive FERPA regula- } \\
\text { tions for DE students }\end{array}$ & 11 & 2.5 & 11 & 2.1 & 9 & 1.7 & 9 & 2.3 \\
\hline $\begin{array}{l}\text { Eliminate academic eligibility re- } \\
\text { quirements }\end{array}$ & 12 & 2.1 & 12 & 1.9 & 12 & 1.1 & 12 & 2.0 \\
\hline $\begin{array}{l}\text { Eliminate grade-level eligibility re- } \\
\text { quirements }\end{array}$ & 12 & 2.1 & 13 & 1.8 & 11 & 1.3 & 12 & 2.0 \\
\hline
\end{tabular}

Note. Mean $(\bar{x})$ derived from rating scale: $1=$ Very low priority, $2=$ Moderately low priority, $3=$ Slightly low priority, $4=$ Slightly high priority, $5=$ Moderately high priority, $6=$ Very high priority. Recoded to 4-point scale for easier comparison to barriers. 
and institutional ability to participate need modification. Some legislative action addressing program shortcomings are in progress in the state. At this writing, Michigan Senate Bill 623 to amend the Career and Technical Preparation Act has been passed by the Senate and is now in the House (Michigan Legislature, 2011b). Unfortunately, the bill primarily addresses the inclusion of home-schooled students and limits the number of courses students can take, and does not change institutional eligibility or student academic eligibility requirements.

School participants view expansion of inschool programs as very beneficial to programmatic expansion as a whole. There was strong consensus among superintendents and principals that their own schools should expand Advanced Placement programming. This method of expansion is relatively safe for school districts, since it allows the school to retain programmatic control and does not require significant funds to leave the school. College administrators viewed this as a less desirable option, however.

Mixed results were noted with regard to increasing counseling services for dually enrolled students, which was highly supported by college administrators but was only moderately endorsed by school officials. Creation of a common K-16 database of student records was only moderately supported by superintendents and college administrators; and minimally supported by principals.

\section{Program Expansion Priority}

To gauge the importance of postsecondary programs, participants were also asked to rate the importance of expanding postsecondary options for students at this time, and at some point in the future when economic conditions improve (utilizing a 10-point scale, see Table 8). All groups indicated that increasing options for students is important now (10-point scale: $\bar{x}=7.0)$, and slightly more important in the future once financial conditions improve $\overline{(x}=8.0)$. College administrators indicated that increases in options were more important now than either superintendents or principals.

Among the subgroups, superintendents had the lowest opinion of program expansion as a current priority and the highest priority when economic conditions improve, indicating a desire for conservation of resources at the current time. Principals and college administrators shared the opinion that program expansion should be a slightly increased priority when conditions improve. All groups, however, indicate that postsecondary program expansion is important, even during stressful economic times.

\section{Discussion and Implications}

Overall, our study revealed that administrative stakeholders from different organizations perceive different barriers and solutions to postsecondary option expansion in Michigan. These viewpoints arise from the lived experi-

Table 8

Importance of Expansion of Postsecondary Options

\begin{tabular}{|c|c|c|c|c|c|c|c|c|}
\hline & \multicolumn{2}{|c|}{$\underline{\text { District }}$} & \multicolumn{2}{|c|}{ School } & \multicolumn{2}{|c|}{ College } & \multicolumn{2}{|c|}{ Total } \\
\hline & Current & Future & Current & Future & Current & Future & Current & Future \\
\hline$\overline{\bar{x}}$ & 6.9 & 8.1 & 7.1 & 8.0 & 7.7 & 7.8 & 7.0 & 8.0 \\
\hline
\end{tabular}

Note. Mean $(\overline{\mathrm{x}})$ derived from scale: $1=$ Not at all Important, to $10=$ Extremely Important. 
ences of the individuals involved, combined with the real and perceived roles of their counterparts in education.

\section{Connection to Theory and Perceptual Differences}

Stakeholder theory suggests that those individuals who either can affect organizational achievements, or are themselves affected by the policies or practices of an organization, have legitimate interests in both the procedural and substantive aspects of organizational activity (Carroll, 1996; Donaldson \& Preston, 1995; Freeman \& McVea, 2001). Individuals accrue some satisfaction by working within an organization to improve it, and can positively or negatively affect outcomes (Buchholz \& Rosenthal, 2005; Freeman, 1984). Consequently, externally imposed regulations and mandates implemented without perceived stakeholder input can be a barrier to effective local-level program management

In our study, stakeholders tended to identify barriers that were outside their own control as being the most significant, which aligns with expected results from theory. For example, school superintendents identified the state, colleges, students, and geographical distance as sources of the greatest barriers. Principals identified issues with the colleges and students as primary barriers, but also implicated the state. Principals also accepted the least blame for their institutions being the cause of barriers. College administrators identified student issues as the primary barriers, but were also critical of the state, with little self-blame ascribed.

Specific examples can be found in the sorted rankings of barriers (in Table 2) that demonstrate some interesting response dichotomies between stakeholder groups. One is that both superintendents and principals identified "limited acceptance of dual enrollment credit by colleges" as the third most significant barrier, whereas college respondents rated this last (17th) of all identified barriers. Another finding of interest is that college administrators indicated that student-related concerns were the most significant barriers, ranking student maturity (1), study skills (2), and academic ability (tied for third) extremely highly. Both superintendents and principals rated these as mid-level concerns.

Overall, our findings suggest that school and college participants interpret barriers to increased dual enrollment perceptually differently. School officials see systemic issues as the primary concerns holding back expansion and college officials view participant concerns as most significant. This difference could be reflective of a difference in ideology regarding the need to change the existing system, be a consequence of differing perceptions of degree of stakeholder inclusion, or it could be related to different ideas regarding the degree to which the current system needs overhaul.

It is possible that school officials, those with the most fiscal liability in postsecondary options for high school students, view systemic change as essential to rectify problems that cannot be fixed through mere tweaking. Conversely, under the current model, colleges primarily benefit from dual enrollment through increased tuition dollars and increased enrollment, which can mean additional per capita state funding. From this vantage point, any problems with expansion are not likely due to a problem with how the program is designed, constructed, or implemented, but rather with the quality of the population of individuals served. Barriers to expansion, therefore, are viewed as arising from limitations within the population being served.

\section{Identification of Barriers}

In reference to the three specific barriers identified in this report for closer scrutiny, we find some support for concerns when compared to policy norms across the nation. These topics are addressed individually below.

\section{Funding of Postsecondary Options}

The funding burden for dual enrollment in Michigan falls quite heavily on the local 
school districts. Studies demonstrated that only 38 of the states had policies or regulations regarding dual enrollment in the mid2000s, and only 18 had mandates regarding services. Michigan is in this latter category (Karp et al., 2004; Karp, Bailey, Hughes, \& Fermin, 2005c).

Barnett and Stamm (2010) examined payor mixes for dual enrollment across the U.S. and found that the school district in only six states (including Michigan) is responsible for these costs. In 22 states, the student is responsible, in three states the college assumes the burden, in an additional three states the funds come from a separate state pool, and six states have no specified policy. Michigan, therefore, is in a minority of states with regard to the funding burden placed on schools.

\section{Student Access and Credit Acceptance}

As previously noted, the concept of postsecondary coursework during high school has historically been viewed in the purview of gifted and talented education, and inequalities of access due to socioeconomic and ethnic factors have been identified. In Michigan, participation in dual enrollment is currently restricted to students who have exhausted high school course offerings in a given area, but students must have successfully passed proficiency tests in all areas prior to enrolling, not just in the fields they wish to dual enroll. The regulations and promulgated rules in Michigan are currently fluid, and active legislation may change requirements in the state (Michigan Legislature, 2011a, 2011b).

Several studies suggest that dual enrollment is beneficial for a broader range of students than traditionally enrolled (Bailey, 2005; Barnett \& Stamm, 2010; Brand, 2005; Hughes, Karp, Bunting, \& Friedel, 2005). Brand (2005), for example, found that high school students of differing abilities involved in dual enrollment all benefited by taking more rigorous courses and developing higher postsecondary aspirations. She also found preliminary evidence of increased grades and test scores. Given that, a movement toward more inclu- sive dual enrollment policies may be warranted.

Karp et al. (2004) indicated that 29 of 38 states with dual enrollment policies have some policy language that addresses student eligibility, with 17 of these restricting participation by grade level. Of these, Michigan is one of only two states with proficiency requirements (the other being Texas).

In our study, a significant focus was on dual enrollment credit acceptance by colleges. Karp et al. (2004) found that few states dictate the method of credit earning, although most imply that the college transcript speaks for itself. Only 11 states directly require some level of quality control accountability, and Michigan and California are the only two states that have program finance reporting requirements.

Other than cases previously cited, the literature is essentially silent on the issue of credit acceptance for the two most common forms of credit earning options, advanced placement and dual enrollment, although numerous articles in the popular press indicate that some colleges have issues accepting credits from the programs (Holloway, 2010; Roviere, 2007). In Michigan, this had led to confrontations between colleges and legislators in the past (Byrne, 2002). Our findings demonstrate a potential disconnect between the perceived value of postsecondary programs to secondary schools and their associated costs. This is in part due to the insecurity of credit attainment following course completion. Colloquial comments by school officials indicate that, with regard to dual enrollment, lack of communication about failing students and limited credit transference between institutions make the program less optimal.

\section{Student Preparedness and Instruc- tional Skill}

A dichotomy of perception of student preparedness was demonstrated between college and school administrators. College admissions officers identified concerns with student ability, maturity, and study skills as the top barriers to increasing postsecondary options for secon- 
dary students. District superintendents and school principals identified the issues as nontrivial concerns, and ranked them considerably lower.

Indeed, 75 percent of college respondents in our study did not believe that instructors' teaching methodology was an issue with regard to dual enrollment, an opinion shared by about half of the superintendents and principals (Table 6). This difference may be explained by conflicting beliefs regarding student and instructor roles that are inherently different between college and high school.

The primary difference associated with teaching in high school and college is that high school instruction has been historically extrinsic, with instruction being teachercentered. College education is more intrinsic, with students responsible for much of the acquisition of knowledge (Pew, 2007). In this model, college student success depends on the student's ability to transform a lifelong learning pattern in a relatively short time. As noted in this article, the burden of change is essentially placed on the student, with research to support this primarily focusing on increasing motivation (Campbell, Baronina, \& Reider, 2003; Kennelly \& Monrad, 2007; Pew, 2007) or college readiness (Callan et al., 2006; Conklin \& Sanford, 2007). The literature is essentially silent regarding instructional transformation across the high school-college boundary. Given this, it is understandable that high school participants believe the burden of student success in college unfairly falls on them.

\section{Perceived Solutions to Increase Participation}

In reference to solutions, there was great interest among participants for increasing postsecondary options to a broader ability-range of students, which is essential if a 50 percent participation rate is to be achieved (as suggested by the Cherry Commission). Nonetheless, superintendents and principals liked the idea of increasing AP offerings and teaching college courses in high schools, and college respon- dents favored expanding traditional dual enrollment (Table 8), both of which would primarily favor traditional college-bound students.

Other highly ranked solutions call for expanding dual enrollment options in career and technical preparatory courses, and to allow organizations other than colleges to offer dual enrollment (although the higher education officials were less keen on the latter suggestion). Expanding early and middle colleges and offering financial aid to dually enrolled high school students were moderately supported suggestions that would help broaden the nontraditional, dually enrolled student pool. Such changes are also supported by previous research. Bailey and Karp (2003) indicated that, although it might seem counterintuitive, providing postsecondary options for students other than the most academically proficient has benefits. They suggest that increased exposure to college courses raises the student's exposure to academic rigor, provides a realistic guide to the types of skills needed to succeed in college, and allows faculty at the high school and college to work more closely together to ensure student success. Unfortunately, although espousing increases in programs for less-talented students, study participants were diametrically opposed to reducing either grade or ability level requirements for program participation, effectively negating the desire to broaden the scope of dual enrollment.

Improved academic and ancillary advising for dually enrolled students was strongly supported by college respondents, and received somewhat strong support from school and district officials. This naturally corresponds to the college administrator belief that the biggest program problems are student-based. No respondents offered concrete suggestions for accomplishing this advising, but one superintendent suggested implementing a "transitions" course in the high school to provide students with a precursor college experience would be helpful; an idea also supported by high school counselors in a different unpublished work (Wozniak, 2009). 


\section{Conclusion}

Our study revealed that there were, despite some differences, many similar perceptions among stakeholders for moving postsecondary options forward in Michigan. Although it is a common belief that huge injections of new funding would be needed to significantly increase participation, these stakeholders identified a number of policy changes that would require little additional funding to implement, but would demand some political will (e.g., allowing organizations other than higher education to offer dual enrollment, shifting more of the current financial burden to higher education or the student, and making financial aid available to dually enrolled students). The principals and superintendents in our study frequently perceive their institutions as responsible for the brunt of adaptation and responsibility when change occurs in postsecondary options programs. The law is pointed most directly at them, they are fiscally responsible for the activities, and partner colleges may or may not adapt to make program operations easier. As legitimate stakeholders, it is easy to see how school officials can perceive themselves as being outside the sphere of decision making, and they have a definite interest in both the substantive and formative aspects of policy (Buchholz \& Rosenthal, 2005).

That being said, our study results show that all administrator groups believe that postsecondary options expansion is important not only in the future, when economic conditions improve in Michigan, but also right now, in the midst of what is likely the worst financial crisis the state has ever had. With the likelihood of forthcoming funding expansion for these programs being extremely remote, the state should take the gloves off the institutions that educate our students and let them independently explore novel collaborative possibilities now limited by existing policies. Capable and caring educators, working together toward a common goal, might just come up with solutions to many problems without the need for vast influxes of new capital.

\section{References}

Bailey, T. R. (2005). Expanding the reach of dual-enrollment programs. Community College Journal, 75, 8-11.

Bailey, T. R., \& Karp, M. M. (2003). Promoting college access and success: A review of credit-based transition programs. Community Colleges. Retrieved October 2, 2008, from http://www.ed.gov/about/offices/list/ovae/pi /cclo/crdbase.doc

Barnett, E., \& Stamm, L. (2010). Dual enrollment: A strategy for educational advancement of all students. Washington, DC: Blackboard Institute.

Berg-Anderson, R. E. (2011). 2010 Census: State population and the distribution of electoral votes and representatives. Retrieved from http://www.thegreenpapers.com/Census10/ HouseAndElectors.phtml

Brand, B. (2005, April). Dual enrollment and disadvantaged youth. Paper presented at the AERA Annual Meeting, New York. Retrieved from http://ccrc.tc.columbia.edu/Publication.asp? uid $=299$

Buchholz, R. A., \& Rosenthal, S. B. (2005). Stakeholder theory and public policy: How governments matter. Journal of Business Ethics, 51, 143-153.

Burt, D., \& Snyder, S. (Producer). (2006). The challenges of dual enrollment: Administrative barriers in course delivery and support for dual enrollment students. [PowerPoint]. Kalamazoo, MI: Western Michigan University.

Byrne, C. (2002, February 1). MSU nixes dual enrollment credits; legislators complain, Capital News Service. Retrieved from http://cns.jrn.msu.edu/articles/2002_0201/d ualenrollment.html 
Callan, P. M., Finney, J. E., Kirst, M. W., Usdan, M. D., \& Venezia, A. (2006). Claiming common ground: State policymaking for improving college readiness and success. (NCPPHE Report 06-1). Retrieved from The National Center for Public Policy and Higher Education website:

http://www.highereducation.org/reports/co mmon_ground/common_ground.pdf

Campbell, S. V., Baronina, T., \& Reider, B. P. (2003). Using expectancy theory to assess group-level differences in student motivation: A replication in the Russian far east. Issues in Accounting Education, 18(2), 125-136.

Carroll, A. B. (1996). Business and society: Ethics and stakeholder management (3rd ed.). Cincinnati, OH: Southwestern.

Cherry Commission. (2004). Final report of the Lt. Governor's commission on higher education and economic growth. Lansing: State of Michigan. Retrieved from http://www.cherrycommission.org

Conklin, K. D., \& Sanford, S. (2007). A college-ready nation: An idea whose time has come. In N. Hoffman, J. Vargas, A. Venezia \& M. S. Miller (Eds.), Minding the gap: Why integrating high school with college makes sense and how to do it (pp. 65-72). Cambridge, MA: Harvard Education Press.

Donaldson, T., \& Preston, L. E. (1995). The stakeholder theory of the corporation: Concepts, evidence, and implications. Academy of Management Review, 20, 65-91.

Freeman, R. E. (1984). Strategic management: A stakeholder approach. Boston: Pitman.

Freeman, R. E. (1998). A stakeholder theory of the modern corporation. In M. B. E. Clarkson (Ed.), The corporation and its stakeholders: Classic and contemporary readings ( $p p$. 125-138). Toronto: University of Toronto Press.

Freeman, R. E., \& McVea, J. (2001). A stakeholder approach to strategic management. In M. Hitt, E. Freeman \& J. Harrison (Eds.), Handbook of Strategic Management (pp. 189-207). Oxford: Blackwell Publishing.
Frenette, M. (2006). Too far to go on? Distance to school and university participation. Education Economics, 14(1), 31-58.

Fuhrman, S. H., Clune, W., \& Elmore, R. F. (1988). Research on education reform: Lessons on the implementation of policy. Teachers College Record, 90(2), 237-258.

Hagedorn, L. S., \& Fogel, S. (2002). Making school to college programs work. In W. G. Tierney \& L. S. Hadedorn (Eds.), Increasing access to college: Extending possibilities for all students (pp. 169-194). Albany, NY: State University of New York.

Hiemstra, R., \& Sisco, B. (2007). Moving from pedagogy to andragogy. Individualizing Instruction. Retrieved from http://www-distance.syr.edu/andraggy.html

High School Leadership Summit. (2004). Dual enrollment: Accelerating the transition to Hoffman college. Washington, DC: U.S. Department of Education.

Hoffman, N. (2005). Dual enrollment as a state strategy to increase postsecondary success for underrepresented students Add and Subtract (Vol. 2008). Boston, MA: Jobs for the Future.

Hoffman, N., \& Vargas, J. (2005). State policies to support and sustain early college high schools. Retrieved from http://ccrc.tc.columbia.edu/Publication.asp? uid $=300$

Holloway, K. (2010, March 14, 2012). Not all colleges accept dual-credit hours amassed by Texas high school students, Dallas Morning News. Retrieved from http://www.dallasnews.com/news/education /headlines/20101103-Not-all-colleges-accep t-dual-credit-6829.ece

Hughes, K. L., Jacobs, J., \& Karp, M. M. (2006). Recommendations for dual enrollment policy in Michigan from the National Governor's Association Grant Leadership Team and the College Credit Subcommittee. New York: Community College Research Center. 
Hughes, K. L., Karp, M. M., Bunting, D., \& Friedel, J. (2005). Dual enrollment/dual credit: Its role in career pathways. In D. M. Hull (Ed.), New career pathways: Education with a purpose (pp. 226-255). Waco, TX: National Tech Prep Network.

Hughes, K. L., Karp, M. M., Fermin, B. J., \& Bailey, T. R. (2005). Pathways to college access and success. Washington, DC: U. S. Department of Education.

Karp, M. M., Bailey, T. R., Hughes, K. L., \& Fermin, B. J. (2004). State dual enrollment policies: Addressing access and quality. Washington, DC: U. S. Department of Education.

Karp, M. M., Bailey, T. R., Hughes, K. L., \& Fermin, B. J. (2005a). Balancing access and quality: State dual enrollment policies. Washington, DC: U.S. Department of Education.

Karp, M. M., Bailey, T. R., Hughes, K. L., \& Fermin, B. J. (2005b). Dual enrollment: A new major trend. College and Career Transitions Initiative, Alert Report \#21 (November). Washington, DC: U.S. Department of Education.

Karp, M. M., Bailey, T. R., Hughes, K. L., \& Fermin, B. J. (2005c). Update to state dual enrollment policies: Addressing access and quality. Washington, DC: U.S. Department of Education.

Kennelly, L., \& Monrad, M. (Eds.). (2007). Easing the transition to high school: Research and best practices designed to support high school learning. Washington, DC: National High School Center at the American Institutes for Research.

Kleiner, B., Lewis, L., \& Greene, B. (2005). Dual enrollment of high school students at postsecondary institutions: 2002-03. Washington, DC: U. S. Department of Education.

Lerner, J., \& Brand, B. (2006). The college ladder: Linking secondary and postsecondary education for success for all students. Dual/Concurrent Enrollment. Retrieved from http://www.ecs.org/html/IssueSection.asp? is sueid $=214 \& s=$ Selected + Research $+\% 26+$ Rea dings
Mackinac Center for Public Policy. (2006). School districts wrestle high health care costs. Michigan Education Report, Winter/ Spring. Midland, MI: Author.

Michigan Department of Education. (2004). Postsecondary enrollment options act 160 of 1996: Frequently asked questions. Lansing, MI: Author.

Michigan Department of Education. (2006a). The Michigan high school initiative: Secondary to postsecondary transitions action team report. Lansing, MI: Author.

Michigan Department of Education. (2006b). Postsecondary enrollment options Act 160 of 1996: 2006 dual enrollment frequently asked questions. Lansing, MI: Author.

Michigan Department of Education. (2007). 2005-2006 report to the house and senate fiscal agencies $\mathcal{E}$ the Department of Management and Budget. Lansing, MI: Author.

Michigan Department of Education. (2008). Dual enrollment. Lansing, MI: Author.

Michigan Department of Education. (2012). Fiscal Agency Cooperative Agreements. Lansing, MI: Author.

Michigan Legislative Council. (1996). Postsecondary enrollment options act: Act 160 of 1996 Act 160 of 1996. Lansing, MI: Author.

Michigan Legislative Council. (2000). Career and technical preparation act: Act 258 of 2000. Lansing, MI: Author.

Michigan Legislature. (2011a). Senate Bill 0622. Lansing, MI: Author.

Michigan Legislature. (2011b). Senate Bill 0623. Lansing, MI: Author.

Pew, S. (2007). Andragogy and pedagogy as foundational theory for student motivation in higher education. InSight, 2. Retrieved from http://www.insightjournal.net/Volume2.ht $\mathrm{m}$

Porter, R. M. (2003). A study of students attending Tennessee Board of Regents universities who participated in high school dual enrollment programs. Ph.D., (Doctoral dissertation, East Tennessee State, 2003). Available from Proquest UMI database. 
Roviere, J. (2007). Why some colleges no longer accept advanced placement credits. Helium. Retrieved from http://www.helium.com/items/286566-whysome-colleges-no-longer-accept-advanced-p lacement-ap-credits

Rusaw, C. A. (2007). Changing public organizations: Four approaches. International Journal of Public Administration, 30(3), 347361.

Secondary to Postsecondary Transitions Action Team. (2006). The Michigan high school initiative action team report. Retrieved from http://www.michigan.gov/documents/mde/ Final_Report_200605Action_Team_ Summers-Coty Report_174586_7.pdf
Vargas, J. (2004). Dual enrollment: Lessons from Washington and Texas. In R. Kazis, J. Vargas \& N. Hoffman (Eds.), Double the numbers: Increasing postsecondary credentials for underrepresented youth ( $p p$. 205212). Cambridge, MA: Harvard University Press.

Wozniak, C. (2009). College readiness and post-secondary options in Michigan: Barriers to success and recommendations for future actions. Report. Northern Michigan University. Marquette, MI.

Wozniak, C. (2010). Administrator Perspectives of Post-secondary Educational Opportunities for Michigan High School Students. (Doctoral dissertation). Retrieved from UMI. (3470414).

IJEPL is a joint publication of the Association for Supervision and Curriculum Development, the Faculty of Education at Simon Fraser University, and the College of Education and Human Development at George Mason University. By virtue of their appearance in this open access journal, articles are free to use, with proper attribution, in educational and other non-commercial settings 90 days after initial publication. Copyright for articles published in IJEPL is retained by the authors. More information is available on the IJEPL Web site: http://www.ijepl.org 